УДК 621.313.175.32

\title{
ВЕНТИЛЬНІ РЕАКТИВНІ ДВИГУНИ. СУЧАСНИЙ СТАН І ПЕРСПЕКТИВНІ НАПРЯМИ ДОСЛІДЖЕНЬ
}

Канд. техн. наук О.Є. Зінченко

\section{ВЕНТИЛЬНЫЕ РЕАКТИВНЫЕ ДВИГАТЕЛИ. СОВРЕМЕННОЕ СОСТОЯНИЕ И ПЕРСПЕКТИВНЫЕ НАПРАВЛЕНИЯ ИССЛЕДОВАНИЙ}

Канд. техн. наук Е.Е. Зинченко

\section{SWITCHED RELUCTANCE MOTORS. MODERN STATE AND PERSPECTIVE DIRECTIONS OF SCIENTIFIC RESEARCHES}

Cand. of techn. sciences E.E. Zinchenko

Подано аналіз сучасного стану і перспективних напрямів досліджень при проектуванні вентильних реактивних двигунів. Проаналізовано переваги і недоліки вентильних реактивних двигунів порівняно з іншими типами електричних двигунів. Особливу увагу приділено таким напрямам досліджень: зниження пульсацій електромагнітного моменту і акустичного шуму; математичні моделі і адекватний опис проиесів; регулювання вентильних реактивних двигунів; методики розрахунку.

Ключові слова: електричні двигуни, вентильні реактивні двигуні, аналіз.

Представлен анализ современного состояния и перспективных направлений исследований при проектировании вентильных реактивных двигателей. Проанализированы достоинства $u$ недостатки вентильных реактивных двигателей по сравнению с другими типами электрических двигателей. Особое внимание уделено таким направлениям исследований: снижение пульсаций электромагнитного момента и акустического шума; математические модели и адекватное описание процессов; регулирование вентильных реактивных двигателей; методики расчета.

Ключевые слова: электрические двигатели, вентильные реактивные двигатели, анализ. 
The analysis of the modern state and perspective directions of researches is presented at planning of switched reluctance motors. The paper presents a brief review of evolution of switched reluctance motors. Dignities and lacks of switched reluctance motors are analyses as compared to other types of electric motors. The special attention is spared to such directions of researches: decline of pulsations of electromagnetic moment and acoustic noise; mathematical models and adequate description of processes; adjusting of valve ramjets; methodologies of calculation. In the article the analysis of directions of researches is given on the decline of pulsations of moment and acoustic noise. Exactness of mathematical specification of parameters and descriptions of engine is determined by the degree of adequacy of mathematical model, fixed in his basis. Actuality of choice of control system and control algorithms is shown. The analysis of design calculation of geometrical sizes of the magnet core of the switched reluctance motors. The criteria of calculation are shown.

Keywords: electric motors, switched reluctance motors, analysis.

Вступ. Постійне вдосконалення технології виробництва в різних галузях промисловості i автоматизація виробничих процесів обумовлюють постійне збільшення кількості регульованих приводів. До появи силових напівпровідникових приладів у регульованих приводах використовувалися двигуни постійного струму. Через низьку надійність щітково-колекторного вузла, високу вартість і велику масу двигуни постійного струму повною мірою не відповідали вимогам розробників регульованих приводів.

На початку 80 -х років минулого століття в західних джерелах з'явилися публікації про новий тип електричного двигуна, у якому комутація фаз обмотки статора здійснюється за допомогою напівпровідникового комутатора. У західній класифікації цей тип двигуна отримав назву Switched Reluctance Motor (SRM), a привод на їх основі - Switched Reluctance Drive (SRD) [1]. В Україні він отримав акронім ВРД вентильний реактивний двигун. Подальший розвиток цього типу привода показав перспективність досліджень у цій галузі.

Аналіз останніх досліджень та публікацій. Основні положення основи теорії ВРД, питання динаміки i побудови математичних моделей, питання регулювання розглянуто в роботах [1-4]. ВРД - новий тип електромеханічного перетворювача енергії, який динамічно розвивається, i кількість публікацій зростає в геометричній прогресії. Виникає потреба в аналізі й узагальненні інформації, виявленні тенденцій розвитку.

Метою роботи $\epsilon$ аналіз сучасного стану $\mathrm{i}$ перспективних напрямів досліджень при проектуванні вентильних реактивних двигунів.

Основна частина.
термін «ного електромеханічного перетворювача може застосовуватися цілком умовно, оскільки перші розробки необхідно віднести до $30-x$ років XX століття i навіть на першу половину XIX століття. Але численні недоліки механічного комутатора, а потім малорозвиненість електроніки відклали дослідження на десятиліття.

До появи потужних силових напівпровідникових приладів регульовані електроприводи оснащувалися двигунами постійного струму, працюючими або автономно, або в системі генератор-двигун. Такі електроприводи були дорогими $\mathrm{i}$ недостатньо надійними через щітковоколекторні вузли машин постійного струму.

Останне десятиліття ХХ століття ознаменувалося значними успіхами силової електроніки. Було освоєно промислове виробництво біполярних транзисторів 3 ізольованим затвором (IGBT) і польових транзисторів (MOSFET), силових модулів на їх основі, а також силових інтелектуальних модулів (IPM) з вбудованими засобами захисту ключів i інтерфейсами для безпосереднього підключення до мікропроцесорних систем керування.

Завдяки цьому альтернативою колекторним приводам постійного струму стали приводи 3 вентильними, тобто електронно-комутованими двигунами 3 постійними магнітами на роторі. Цей тип привода $\epsilon$ найбільш перспективним для верстатобудування і робототехніки, проте й найдорожчим. Це призвело до того, що регульовані приводи стали створюватися на асинхронних двигунах (АД) 3 частотними перетворювачами. Нині постійно розширюється виробництво приводів на основі 
ВРД. Двигуни цього типу прості у виготовленні, технологічні i дешеві. Вони мають пасивний феромагнітний ротор без якихнебудь обмоток або магнітів.

Проведений аналіз [1-12] показав ряд переваг ВРД:

1) ВРД має однаковий або більший, чим у АД, ККД електромеханічного перетворювача, особливо при низьких частотах обертання, більший, ніж у машин постійного струму, але менший, ніж у вентильних двигунів (ВД), хоча вартість ВРД у 2-3 рази менша;

2) ВРД добре керується зміною параметрів імпульсів напруги. При несуттєвому ускладненні комутатора можна досягти істотного зниження пульсації моменту;

3) ВРД менш чутливий до зміни параметрів, ніж асинхронний двигун, оскільки його ротор не має обмотки і схемних рішень, що унеможливлюють короткі замикання в ньому, він краще захищений від останніх, ніж будь-який інший двигун. ВРД зберігає працездатність навіть тоді, коли деякі його обмотки вийшли з ладу;

4) частоту обертання ВРД можна змінювати в широкому діапазоні. Верхня межа частоти обертання обумовлена характеристиками застосованих підшипників. Частота обертання ВРД може досягати 100 тис. об/хв;

5) ВРД мають більший максимальний момент, ніж АД, але менший, ніж ВД;

6) при рівній потужності в серійному виробництві ВРД 3 комутаторами дешевше, ніж ВД 3 комутаторами і АД 3 частотними перетворювачами.

Проте разом 3 вказаними перевагами ВРД має i істотні недоліки: пульсації електромагнітного моменту i підвищений акустичний шум [14].

Дослідженнями $[1,15,16]$ встановлено, що акустичний шум обумовлений пульсаціями електромагнітного моменту ВРД. Істотного зниження пульсацій електромагнітного моменту можна досягти формуванням спеціальної форми фазних струмів. Зміною форми заднього фронту хвилі стуму [17] значно можуть бути знижені шум і пульсації моменту. Певне зниження пульсацій електромагнітного моменту досягається [15] компенсацією вищих гармонік потоку. Також можливе зниження шуму і пульсацій моменту за рахунок конструктивних заходів. Проте, незважаючи на великий об'єм досліджень, присвячених цій проблемі, питання остаточно не вирішено і потрібен пошук нових шляхів для його вирішення.

Проектування ВРД неможливе без глибокого розуміння суті електромагнітних i електромеханічних процесів і їх аналітичного опису. У цьому плані вкрай важливим $\mathrm{\epsilon}$ урахування чинників, раніше неохоплених математичною моделлю, i відповідний iіi розвиток i уточнення. Тільки на базі фундаментальних досліджень фізичних процесів у ВРД можуть бути визначені принципи i напрями підвищення їx енергетичних характеристик. Більш того, особливості електромагнітних і електромеханічних процесів у них залежать від схеми застосованого комутатора, від того, до якого джерела живлення, постійного або змінного струму, підключається комутатор ВРД.

Точність математичного опису параметрів i характеристик ВРД цілком визначається мірою адекватності математичної моделі, покладеної в його основу, реальним фізичним процесам, що протікають у двигунах. Нині розроблені математичні моделі дозволяють описувати практично всі електромагнітні і електромеханічні процеси в електричних машинах [2, 3, 4, 17-21]. Проте точність визначення параметрів, характеристик i показників не завжди буває задовільною. Потрібне вдосконалення математичних моделей на базі результатів нових досліджень у галузі теорії електромагнітних i електромеханічних процесів, що забезпечує їх усебічний, повний і адекватний опис.

Комутатори ВРД будуються за схемами, які добре описані $[1,4]$. Вибір схеми залежить від умов роботи і вимог технічного завдання. Завдання, пов'язані з керуванням ВРД, дають широке поле діяльності для досліджень. ВРД характеризуються нелінійністю робочих характеристик магнітної системи, зміною форми імпульсів струмів у фазах залежно від керуючих дій. Тому традиційні алгоритми керування регульованим електроприводом виявляються не пристосованими для ВРД. До теперішнього часу завдання вибору структури системи управління i застосовуваних алгоритмів для конкретного використання залишається актуальним, незважаючи на спостережувану тенденцію до їх уніфікації. 
Що стосується визначення геометричних розмірів сердечників статора i ротора, то 3 цього питання існує декілька підходів $[1,2,3$, 21-25], відповідно до яких виходять різні рішення і не завжди однозначні.

Початковим етапом проектування двигуна $є$ вибір об'єму ротора. Для його визначення [25] рекомендуються два підходи. Перший підхід - визначення об'єму за допомогою сталої машини. Але метод визначення головних розмірів за допомогою сталої машини має істотні недоліки. Стала машини не $\epsilon$ постійною для машин у широкому діапазоні потужностей і швидкостей обертання, оскільки максимальне значення магнітної індукції в повітряному проміжку і лінійне електричне навантаження змінюються зі зміною розмірів машин.

Другий підхід - визначення головних розмірів за довідковими даними, отриманими при проектуванні серійних і дослідних ВРД для різних галузей застосування [1], є більше диференційованим. Як базову величину прийнято питомий момент, що припадає на $1 \mathrm{~m}^{3}$ об'єму ротора. При цьому діапазони питомого моменту досить широкі (1,96 -196 кНм/м³) і при проектуванні конкретного двигуна однозначна відповідь у частині величини питомого моменту не може бути отримана.

Для двигунів 3 ємнісними накопичувачами енергії [4] наведено формули для розрахунку діаметра ротора виходячи 3 лінійного навантаження i вказується досить широкий діапазон співвідношення між діаметром ротора і його довжиною. Але для двигунів різної потужності різне лінійне навантаження, a iï величина залежно від потужності заздалегідь для ВРД не визначена.
У методиці [2] в основу покладено визначення максимального моменту при заданих геометричних розмірах $\mathrm{i}$ заданій щільності струму в обмотці. При цьому слід визначити, якими ж мають бути поперечні геометричні розміри при заданому зовнішньому діаметрі статора, щоб був максимальним момент.

У роботах $[22,24]$ визначення геометричних розмірів магнітопроводу запропоновано брати 3 умови досягнення максимальної енергії магнітного поля в повітряному проміжку або з умови отримання максимального магнітного потоку, що припадає на одиницю струму. Остаточний вибір рекомендується визначати за результатами електромагнітного розрахунку.

Таким чином, напрями дослідження, пов'язані 3 удосконаленням методик розрахунку геометричних розмірів статора $\mathrm{i}$ ротора, як і раніше, $є$ актуальними.

Струми у фазах статора ВРД мають різко несинусоїдний вигляд. Це обумовлює знижену сумісність 3 мережею через високий вміст вищих гармонік. При проектуванні ВРД цим питанням необхідно приділяти більше уваги.

Вдосконалення конструкції, окремих деталей і вузлів актуально для будь-якого типу двигуна, і ВРД не $\epsilon$ тут виключенням. Розробники активно займаються цими питаннями i, поза сумнівом, займатимуться цим надалі.

Висновок. Нині немає однозначних підходів до проектування ВРД, незважаючи на спостережувану тенденцію до їх уніфікації. Усе це залишає широке поле діяльності для наукових досліджень.

\section{Список використаних джерел}

1. Miller, T.J.E. Switched reluctance motors and their control [Text] / T.J.E. Miller // Magna Physics Publishing and Clarendon Press. Oxford, 1993.

2. Голландцев, Ю.А. Вентильные индукторно-реактивные двигатели [Текст] / Ю.А. Голландцев. С.Пб.: ГНЦ РФ - ЦНИИ «Электроприбор», 2003. - 148 с.

3. Кузнецов, В.А. Вентильно-индукторные двигатели [Текст] / В.А. Кузнецов, В.А. Кузьмичев. - М.: МЭИ, 2003. - 70 с.

4. Ткачук, B.I. Електромеханотроніка [Текст]: підручник / В.І. Ткачук. - Львів: Видавництво Національного університету “Львівська політехніка", 2006. - 440 с.

5. Broek, H. van der. Switched reluctance drive and PWM induction motor drive compared for low cost applications [Text] / H. van der Broek, D. Gerling, E. Bolte // EPE'93, 6:71 76, September 1993.

6. Goransson, G. A cost optimised direct drive for low-speed industrial applications [Text] / G. Goransson, L. Sjoberg, J. Reinert // EPE'2001, CD-ROM, August 2001. 
7. Harris, M.R. A review of the integral-horsepower switched reluctance drive [Text] / M.R. Harris, J.W. Finch, J.A. Mallick, T.J.E. Miller // IEEE Trans. on Industry Applications, IA-22(4):716-721, July/August 1986.

8. Kline, J.A. Opportunities for switched reluctance motor-drives [Text] // Pulp and Paper Industry Technical Conference, 1999, 42-47, June 1999.

9. Lawrenson, P.J. A brief status review of switched reluctance drives [Text] / P.J. Lawrenson // EPE Journal. 2(3):133-138, October 1992.

10. Miller, T.J.E. Optimal design of switched reluctance motors [Text] / T.J.E. Miller // IEEE Trans. on Industrial Electronics, 49(1):15-27, February 2002.

11. Calverley, S.D. Design of a high speed switched reluctance machine for automotive turbogenerator applications [Text] / S.D. Calverley, G.W. Jewell, R.J. Saunders // SAE Transactions, 108(2):3246-3255, 2000.

12. Hendershot, J.R. AC, brushless and switched reluctance motors comparisons [Text] / J.R. Hendershot // Motion Control, 1 - 12, April 1991.

13. Бычков, М.Г. Экспериментальные исследования шума и вибраций в вентильноиндукторном электроприводе [Текст] / М.Г. Бычков, А.В. Кисельникова, В.А. Семенчук // Электричество. - 1997. - №12. - С.41-46.

14. Красовский, А.Б. Физические особенности алгоритма компенсации пульсаций момента в вентильно-индукторном электроприводе [Текст] / А.Б. Красовский // Тезисы II Междунар. конф. “Состояние разработки и перспективы применения вентильно-индукторных приводов в промышленности и на транспорте”. - М.: Интерэлектро, 2001. - С. 40-45.

15. Красовский, А.Б. Исследование пульсаций момента в вентильно-индукторном электроприводе [Текст] / А.Б. Красовский, М.Г. Бычков // Электричество. - 2001. - №10. - С. 30-33.

16. Голландцев, Ю.А. Пульсации пускового момента вентильного индукторно-реактивного двигателя [Текст] / Ю.А. Голландцев // Электричество. - 2003. - № 6. - С.21-24.

17. Ильинский, Н.Ф. Вентильно-индукторный привод для легких электрических транспортных средств [Текст] / Н.Ф. Ильинский, М.Г. Бычков // Электротехника. - 2000. - №2. - С. 28-31.

18. Kosaka T. Denki gakkai ronbunshi. D. Sangyo oyo bumonshi [Text] / T. Kosaka, N. Matsui, Y. Taniguchi, H. Do-meki // Trans. Inst. Elec. Eng. Jap. D. - 1998. - 118, №2. - P. 150-157.

19. Рымша, В.В. Математическое моделирование линейных вентильно-реактивных двигателей [Текст] / В.В. Рымша // Електротехніка і електромеханіка. - 2003. - №4. - С. 72-76.

20. Krishnan, R. Switched Reluctance Motor Drives. Modeling, Simulation, Analysis, Design and Applications [Text] / R. Krishnan - CRC Press, 2001. - 398 p.

21. Зинченко, Е.Е. Математическая модель вентильного индукторно-реактивного двигателя, питающегося от выпрямителя [Текст] / Е.Е. Зинченко // Технічна електродинаміка. - 2009. - №4. C. 23-28.

22. Зинченко, Е.Е. Раскрой листов магнитопровода вентильных индукторно-реактивных двигателей [Текст] / Е.Е. Зинченко, В.Б. Финкельштейн // Електротехніка і електромеханіка. - 2008. № 5. - С. 16-19.

23. Ferrero, A. An Indirect Test Method for the Characterization of Variable Reluctance Motors [Text] / A. Ferrero // IEEE, Transactions on Instrumentation and Measurement. - 1993. - Vol. 42, № 6. - P. 1020-1025.

24. Зинченко, Е.Е. Методика расчета вентильного индукторно-реактивного двигателя [Текст] / Е.Е. Зинченко, В.Б. Финкельштейн // Електротехніка і електромеханіка. - 2009. - № 4. - С. 24-29.

25. Кузнецов, В.А. Особенности расчета индукторных двигателей для вентильного электропривода [Текст] / В.А. Кузнецов, Л.А. Садовский, В.Л. Виноградов [и др.] // Электротехника. - 1998. - №6. - C. 35-43.

Рецензент д-р техн. наук, професор М.М. Бабаєв

Зінченко Олена Свгенівна, канд. техн. наук, доцент кафедри електротехніки та електричних машин Українського державного університету залізничного транспрту. Тел.: (057) 730-19-96.

Elena Zinchenko, candidate of engineering, docent department of electrical engineering and electrical machines Ukrainian State University of Railway Transport. Tel.: (057) 730-19-96.

Стаття прийнята 30.10 .2015 p. 